\title{
MENARIK BENANG MERAH HUBUNGAN ACEH DENGAN SULAWESI SELATAN
}

\author{
Reni Juliani \\ Program Studi Ilmu Komunikasi, Universitas Teuku Umar \\ Email: renijuliani@utu.ac.id
}

\begin{abstract}
This article aims to show clearly how the actual relationship Aceh and South Sulawesi in the past and the present, so that the resulting discourse that Aceh and South Sulawesi have a thread that is not interrupted by distance and differences that have.This study uses library research method. the results of this study indicate that red thread of Aceh and South Sulawesi relantionship starts with the spice trade relations, then the marital relationship between Sultan Iskandar Muda and Putroe Suni who are descendants of Bugis, so that it ties to the history of the entry of the Islam religion to South Sulawesi. At present, the red thread is never interrupted Good relations are still maintained. The remnants of historical relics such as tombs of Kings of Aceh who are descendants of Bugis are still preserved right in front of the building of Aceh Museum. Beside the marriage between the two ethnics (Aceh and Bugis Makassar) which have occurred in the past, is still going on today. Marriage of two ethnic groups is growing. Thus, a red thread ties between Aceh and South Sulawesi is getting stronger.
\end{abstract}

Keywords: Red Thread, Aceh, South Sulawesi.

\section{PENDAHULUAN}

Letak geografis antara Aceh dengan Sulawesi Selatan sangatlah jauh. Kedua provinsi ini terpisahkan oleh beberapa pulau. Aceh berada di wilayah paling barat dari Indonesia yaitu berada di paling ujung pulau Sumatera. Sedangkan Sulawesi Selatan berada di Wilayah Tengah Indonesia. Dengan jarak yang begitu jauh, tidak heran apabila antara Aceh dan Sulawesi Selatan banyak memiliki perbedaannya, baik dari segi waktu saja sudah berbeda satu jam. Aceh berada di kawasan Waktu Indonesia Barat (WIB) sedangkan Sulawesi Selatan berada di kawasan Waktu Indonesia Tengah (WITA). Apalagi dari segi budaya dan adat istiadat mereka yang sudah pasti memiliki banyak perbedaan. Kembali lagi kepada bahasa. Jika bahasa lokalnya saja sudah sangat berbeda di Aceh ada beberapa bahasa daerah yaitu Bahasa Aceh sendiri, bahasa Gayo, bahasa Aneuk Jame dan banyak lagi bahasa lokal yang ada di Aceh. Sedangkan di Sulawesi Selatan sendiri juga memiliki bahasa lokal seperti Bahasa Bugis, Makassar, Toraja, Mandar dan bahasa Konjo.

Ketika menyinggung tentang berbagai perbedaan yang dimiliki oleh Aceh dan Sulawesi Selatan, sangat mengherankan bahwa mereka sebenarnya mempunyai benang merah sendiri yang menjadikan Aceh dan Sulawesi Selatan itu terhubung. Seperti yang dijelaskan oleh Triandis (1994) dalam Lubis (2012:27) konflik akan lebih besar jika kedua budaya sangat berbeda dibandingkan jika mereka sama. Namun, yang terjadi antara Aceh dan Sulawesi Selatan ini beda. Walaupun mereka mempunyai perbedaan, mereka tetap bisa akur dan menjaga hubungan baik mereka. 
Hubungan Aceh dengan Sulawesi sangatlah erat. Seperti yang tertulis dalam atjehcyber.net edisi Kamis, 16 Mei 2013, Makassar terpilih sebagai tempat penyelesaian masalah yang dialami oleh Aceh. Tim Pemerintahan Aceh dan Pemerintahan Pusat melakukan perundingan mengenai bendera dan lambing Aceh di Makassar. Dalam pertemuan ini Gubernur Sulawesi Selatan Syahrul Yasin Limpo mengungkapkan bahwa "Antara Aceh dengan Bugis memang punya benang merah sejarah yang tidak dapat dilupakan. Aceh itu milik kita, Sulsel punya hubungan erat dengan Aceh. Aceh dan Sulses memiliki hubungan historis yang panjang. Raja terakhir Aceh merupakan suku Bugis Makassar. Karenya, hubungan historis dan emosional antara masyarakat Aceh dan Sulsel sangat kuat."

Tulisan ini bertujuan untuk memperlihatkan dengan jelas bagaimana sebenarnya hubungan Aceh dengan Sulawesi Selatan di masa lalu dan masa sekarang sehingga timbul wacana bahwa Aceh dengan Sulawesi Selatan mempunyai benang merah yang tidak terputus oleh jarak dan perbedaan yang dimiliki keduanya.

\section{TINJAUAN PUSTAKA}

\section{Etnis Aceh}

Provinsi Aceh memiliki beberapa suku yang tinggal menyebar di setiap daerahnya. Suku-suku tersebut antara lain adalah suku Aceh, suku Aneuk Jamee, suku Gayo, suku Alas, suku Kluet, suku Singkil, suku Tamiang dan suku Simeulu.

Suku bangsa Aceh adalah yang mendominasi mendiami Nanggroe Aceh Darussalam (NAD), terdiri dari 17 kabupaten dan 4 Kotamadya (1999). Wilayah kediaman asli suku bangsa Aceh adalah Kotamadya Banda Aceh, Kotamadya Sabang, Kabupaten Aceh Besar, Kabupaten Pidie, Kabupaten Aceh Utara, sebagian Kabupaten Aceh Barat, sebagian Kabupaten Aceh Selatan dan sebagian Kabupaten Aceh Timur. Suku bangsa Aceh mempunyai bahasa sendiri, yaitu bahasa Aceh yang terdiri dari beberapa dialek, diantaranya dialek Peusangan, Banda, Bueng, Daya, Pasee. Tunong, Matang, Seunangan dan Meulaboh. Dari keseluruhan pada umumnya masyarakat Aceh dapat memahami arti kata-kata dari kalimat yang diucapkan dari perbedaan dialek tersebut (Umar, 2006:69).

Kesultanan Aceh didirikan oleh Sultan Ali Mughayat Syah pada tahun 1496. Pada awalnya kerajaan ini berdiri atas wilayah Kerajaan Lamuri, kemudian menundukan dan menyatukan beberapa wilayah kerajaan sekitarnya mencakup Daya, Pedir, Lidie, Nakur. Selanjutnya pada tahun 1524 wilayah Pasai sudah menjadi bagian dari kedaulatan Kesultanan Aceh diikuti dengan Aru. Kesultanan Aceh Darussalam merupakan sebuah kerajaan Islam yang pernah berdiri di provinsi Aceh, Indonesia. Kesultanan Aceh terletak di utara pulau Sumatera dengan ibu kota Kutaraja [Banda Aceh] dengan sultan pertamanya ialah Sultan Ali Mughayat Syah yg dinobatkan pada pada Ahad, 1 Jumadil awal $913 \mathrm{H}$ atau pada tanggal 8 September 1507. Dalam sejarahnya yg panjang itu [1496-1903], Aceh telah mengukir masa lampaunya dengan begitu megah dan menakjubkan, terutama karena kemampuannya dlm mengembangkan pola dan sistem pendidikan militer, komitmennya dalam menentang imperialisme bangsa Eropa, sistem pemerintahan yg teratur dan sistematik, mewujudkan pusat-pusat pengkajian ilmu pengetahuan, sampai kemampuannya dlm menjalin hubungan diplomatik dengan negara lain (Anonim, 2014).

Keberhasilan gemilang mengusir Portugis, mengukuhkan Sultan Alaidin Ali Mughaiyat Syah secara definitif sebagai Sultan pertama Kerajaan Aceh Darussalam dengan ibukota negara Banda Aceh. Berdirinya Kerajaan Islam Besar pada masa tersebut sekaligus mendudukkan Aceh Darussalam menjadi salah satu Kerajaan Islam Besar yang masuk dalam deretan "Lima Besar Islam". Pada masanya, Lima Besar Islam ini menjalin kerja 
sama ekonomi, politik, militer, dan kebudayaan. Lima Besar Kerajaan Islam tersebut (Jakobi, 2004:17) adalah:

a. Kerajaan Islam Turki Usmaniyah yang berpusat di Istambul, Asia Minor.

b. Kerajaan Islam Maroko di Afrika Utara.

c. Kerajaan Islam Isfahan di Timur Tengah.

d. Kerajaan Islam Agra di Anak Benua India.

e. Kerajaan Aceh Darussalam di Asia Tenggara.

Dari dahulu kala, Aceh terkenal dengan petarung-petarung tangguh dan berani. Selain terkenal dengan wilayah yang kental dengan keislamiannya, daerah Aceh juga kaya akan hasil rempah-rempahnya dan menjadi sorotan bagi penjajah-penjajah yang ingin merebut Aceh. Namun, para penjajah tidak pernah berhasil menaklukkan Aceh. Rakyat Aceh dengan segenap kekuatannya bertarung mengusir para penjajah sehingga mereka berhasil mempertahankan Aceh.

Sultan Ali Mughayat adalah sultan yang pertama sekali merancang bendera Aceh. Bendera aceh yang bersimbolkan bulan, bintang dan pedang di bawahnya. Bendera ini melambangkan Aceh dengan ketangguhannya yang teguh dalam agama Islam. Pada masa Sultan Iskandar Muda, kerajaan Aceh berada pada puncak kejayaan dan kemasyuran. Dan kini bendera tersebut ingin disahkan oleh pemerintahan Aceh menjadi bendera Aceh yang melambangkan kejayaan Aceh sama seperti dahulu pada masa kerajaan Aceh berjaya.

Bagi generasi Aceh, hidup di dunia bukan sekedar hidup. Hidup adalah sebuah kemuliaan. Kita lebih baik mati daripada hidup sebagai budak dari bangsa lain. Aceh tidak pernah bisa diperintah oleh bangsa lain seperti diingatkan dalam hikayat nenek moyang kita (Ditiro, 2013:3):

"Hadjat lon aneuk tadong beukong, Beu meuglong Lagee geupula" (Hikayat Putroë Peukisôn)

Artinya:

"Keinginanku bersikap teguhlah, harus terpacak seperti tertanam" (Hikayat Putroë Peukisôn)

Ungkapan hikayat di atas dimaksudkan bahwa keinginan kuat kita harus kita teguh dan yakinkan. Kita pegang erat-erat. Jangan menyerah sampai keinginan tersebut terlaksana dan impian menjadi kenyataan. Layaknya tanaman yang kita tanam, Beu meuglong Lagee geupula yang berarti harus berdiri kokoh seperti harapan kita saat menanamnya.

Dalam kehidupan orang Aceh, hadih maja merupakan karya sastra (lisan) yang dijunjung tinggi keberadaannya. Bakar, dkk (dalam Harun, 2009:12) menyebutkan bahwa hadih maja berarti ucapan-ucapan yang berasal dari nenek moyang yang tidak berhubungan dengan agama, tetapi ada kaitannya dengan kepercayaan rakyat yang perlu diambil ibaratnya untuk menjamin ketenteraman hidup atau untuk mencegah terjadinya bencana, seperti adat istiadat pada suatu upacara, aturan-aturan berpantangan, ucapan-ucapan mengenai moral, dan lain-lain. Harun (2009:14) menyebutkan sebuah contoh hadih maja yang masih sering diucapkan masyarakat:

Meunyoe teupat niet ngon kasad

Laôt darat Tuhan peulahra

(Kalau benar niat dan maksud

Di laut dan di darat Tuhan pelihara) 
Hadih maja ini bermaksud memberitahukan informasi mengenai perlunya seseorang "membawa diri" dalam pergaulan di mana pun dia berada; di kampung sendiri, terlebih-lebih di rantau orang (Harun, 2009:14).

Berdasarkan hasil kajian terhadap hadih maja yang mengandung nilai filosofis, tampak bahwa orang Aceh memiliki prototipe watak yang:

a. Reaktif,

b. Militan,

c. Optimis,

d. Konsisten, dan

e. Loyal (Harun, 2009:23).

Harun (2009:144) juga menjelaskan bahwa nilai etis pribadi orang Aceh berhubungan dengan:

a. Tahu diri,

b. Teguh pendirian atau istiqamah,

c. Jujur kepada diri sendiri,

d. Setia,

e. Bijak,

f. Malu kepada diri sendiri,

g. Kebersihan diri,

h. Hemat,

i. Rajin,

j. Berani,

k. Empati, dan

1. Berterima kasih.

\section{Etnis Bugis Makassar}

Bugis adalah salah satu bangsa yang mendiami wilayah bagian Selatan pulau Sulawesi yang saat ini dikenal dengan Sulawesi Selatan. Orang Bugis merupakan etnis terbesar dengan prosentase $41,90 \%$ dari jumlah penduduk Sulawesi Selatan (Suryadinata, 2003 dalam Abdullah dkk, 2009:234).

Ibukota Sulawesi Selatan adalah Makassar. Makassar adalah kota pelabuhan terbesar di Sulawesi Selatan, dan sejak abad ke-18. Masehi banyak orang Bugis bermukim di sana. Oleh kerena itu, orang luar biasanya tidak dapat membedakan orang Bugis dengan orang Makassar. Selain itu, kata Bugis dan Makassar sangat sering disandingkan sehingga banyak yang mengira kata Bugis dan Makassar adalah sinonim. Ilmuwan setempat sendiri turut berperan menghilangkan perbedaan kedua suku tersebut dengan kecenderungan mereka menulis kedua istilah tersebut menjadi kata majemuk "Bugis-Makassar" (Mattulada, "Kebudayaan Bugis-Makassar"; "Bugis-Makassar"; Hamid Abdullah, Manusia Bugis-Makassar). Kecenderungan ini memang didasarkan atas kesamaan identitas mereka sebagai sesama muslim yang mengatasi perbedaan suku dan bahasa mereka (Pelras, 2006:16).

Christian Pelras (2006:4) melanjutkan penjelasannya mengenai orang BugisMakassar bahwa semua orang Bugis-Makassar sebenarnya memiliki berbagai ciri khas yang sangat menarik. Mereka adalah contoh yang jarang terdapat di wilayah Nusantara. Mereka mampu mendirikan kerajaan-kerajaan yang sama sekali tidak mengandung pengaruh India, dan tanpa mendirikan kota sebagai pusat aktivitas mereka. Orang BugisMakassar juga memiliki tradisi kesusastraan, baik lisan maupun lisan, hingga kini masih tetap dibaca dan disalin ulang. Perpaduan antara tradisi lisan dan sastra tulis itu kemudian menghasilkan salah satu epos sastra terbesar dunia, yakni La Galigo yang lebih panjang 
dari Mahabharata.

Dalam kesehariannya hingga saat ini orang bugis masih menggunakan bahasa "Ugi" yang merupakan bahasa keluarga besar dari bahasa Austronesia Barat. Selain itu, orang Bugis juga memilikis aksara sendiri yakni Aksara Lontara yang berasal dari huruf Sansekerta. Di kalangan orang Bugis-Makassar masih hidup diantara aturan-aturan yang dianggap luhur dan keramat yang dinamakan panngaderreng atau panngadakkang. Diartikan sebagai keseluruhan norma yang meliputi bagaimana seseorang harus bertingkah-laku terhadap sesama manusia dan terhadap pranata sosialnya secara timbal balik (etika). Orang Bugis sangat menjujung harga diri atau dalam bahasa bugisnya disebut "siri" (malu). Dalam hal ini, barang siapayang menyinggung perasaan mereka atau melanggar adat, maka harus mendapatkan sanksi adat seperti diasingkan, diusir atau bahkan dilenyapkan (Bachtiar, 2014).

Bagi suku-suku bangsa yang tinggal di sekitar orang Bugis, mengenal mereka sebagai orang yang karakter keras dan menjunjung tinggi kehormatan. Bahkan demi kehormatan (siri'). Orang Bugis rela melakukan tindak kekerasan karena siri' merupakan harga diri yang mesti dipertahankan. Karakter keras menjadi label orang Bugis karena keteguhan mempertahankan sesuatu dan keberanian menghadapi tantangan (Abdullah dkk, 2009:236).

Naekiak mau tau pẻlloreng matẻmoi naola amatẻngeng, apak dẻssa temmatuna sininna makẻnyawaẻ. Naia dẻcẻnna asẻraẻ tetakkinik napolẻi karẻba majak karẻba madẻcẻngnge; dẻk najampangiwi karẻba naẻngkalingaẻ, naẻkiak napasilaongngi sennang ati pikkirik madẻcẻngnge; temmutaukni ripariolo; temmitauki ri parimunri; tetteai mita bali; rialai passoppo ri wanuaẻ; matinuluk I pajaji passurong, rialai paddebbang to mawatang; masirik toi riasik toi ri padanna tau. (Pelajarilah perbuatan serta tingkah laku orang berani. Karena perbuatan orang berani sepuluh maca, dan hanya satu keburukkannya jadi sembilan kebaikannya. Sebabnya dikatakan satu keburukkannya karena ia mudah dititih oleh kematian. Namun demikian orang yang penakut pun akan mati jua, sebab tak terelakkan kematian bagi setiap insan yang bernyawa. Adapun kebaikannya yang berjumlah sembilan ialah: Tak terkejut mendengar kabar buruk dan kabar baik; tak mengacuhkan kabar yang didengar; tetapi diiringinya ketenangan serta pikiran sehat; tak gentar dikedepankan; tidak takut dibelakangkan; tak gentar menghadapi musuh; dijadikan perisai negara; rajin melaksanakan suruhan/kewajiban; diambil sebagai pengrebah orang yang berbuat kekerasan/sewenang-wenang; menyegani orang lain dan disegani pula oleh orang lain (Andi Zainal Abidin Farid dalam Hamid, 2003:36).

La side'Dg Tapala (1997) menjelaskan bahwa siri' dalam arti harkat dan martabat, dan tidak dalam arti lain seperti "malu-malu, malu biasa, segan, takut, atau dengki". Penjelasan dari Andi Zainal Abidin Farid mengenai siri' antara lain (Hamid, 2003:35):

Asirik mẻtauk I dewata Seuaẻ, asiri' I alẻmu, asiri' I padammu rupa tau, siri' I bali wanuammu. (Hormat, harkat dan martabat serta takutlah pada Tuhan Yang Maha Esa, jagalah harkat dan martabatmu, harkat dan martabat sesamamu dan orangorang di negara tetanggamu).

Naia riasengnge siasiri' sipakataukik siakka siri'sekkik. (Yang disebut saling menghormati harkat dan martabat ialah kita harus saling memperlakukan secara manusiawi, dan saling membela harkat dan martabat masing-masing).

Narẻkko muẻloriwi atinna padammu rupa tau abbẻrẻang toi atimmu. (Kalau engkau mengharapkan hati sesamamu manusia, berikanlah juga hatimu). 
Dapat diambil kesimpulan bahwa siri' yang dimaksudkan oleh Andi Zainal Abidin Farid bukan berarti budaya malu, melainkan harga diri, harkat dan martabat. Terlebih lagi di depan Maha Pencipta haruslah takut dan selalu berbuat baik kepada sesama manusia. Saling melindungi, menghormati dan menyayangi. Karena menurutnya apabila seseorang ingin mengharapkan kebaikan, maka lakukanlah kebaikan itu.

Bagi orang Bugis-Makassar, siri'merupakan nilai yang bersifat fundemental. Siri' sangat mencerminkan budaya Bugis-Makassar itu sendiri. Mattulada menjelaskan beberbagai masalah esensial dalam ukuran nilai yang diperkirakan menyangkut makna siri' dapat dikemukankan sebagai berikut:

a. Siri' sebagai "harga diri” (dignity), harga diri adalah kelayakan dalam kehidupan sebagai manusia yang diakui dan diperlakukan sama oleh setiap orang terhadap sesamanya. Orang yang tidak memperoleh perlakuan yang layak dari sesamanya itu merasa "harga dirinya" terlanggar.

b. Siri' sebagai "keteguhan diri", seseorang yang mempunyai keteguhan hati adalah seseorang yang mampu menentukan sikap sesuai dengan kebenaran dari ketetapan hati nuraninya yang benar. Ia tidak mudah terombang-ambing oleh desakan atau ancaman dari luar dirinya (Hamid, 2003:48).

\section{Etnis Bugis Makassar di Aceh}

Bugis Makassar adalah suku yang berasal dari Sulawesi Selatan. Suku inilah yang menjalin hubungan dengan suku Aceh. Marzuki SB menjelaskan dalam opininya di aceh.tribunnews.com edisi 28 Oktober 2012 bahwa "Suku Bugis Makassar merupakan sebuah komunitas yang pernah hidup dan berkembang di Aceh. Suku Bugis Makassar berasal dari Sulawesi Selatan. Pada Abad ke 16-17 orang-orang Bugis Makassar masuk ke Aceh sebagai pedagang rempah-rempah. Dalam beberapa tulisan diceritakan bahwa suku Bugis Makassar, selain berperan sebagai pedagang rempah-rempah, juga mempunyai pengaruh besar di masa kesulthanan kerajaan Aceh masa Iskandar Muda." Hal ini terbukti melihat sisa peninggalan sejarah yang ada di Museum Aceh. Salah satunya adalah makan Raja-raja Aceh keturunan Bugis Makassar yang masih ada tepat di depan bangunan Museum Aceh.

Siapakan masyarakat Bugis Makassar yang ada di Aceh? Historiografi tradisional yang pernah berkembang di Aceh menyebutkan silsilah Sultan Aceh keturunan Bugis diawali dengan kisah seorang bernama Daeng Mansyur dari Wajo (kini salah satu Kabupaten di Provinsi Sulawesi Selatan). Ia seorang anak raja yang terdampar di perariran Pidie (kini Kabupaten Pidie di Provinsi Nanggroe Aceh Darussalam). Disisi lain kita akan bercerita tentang sebuah kampung (Aceh: Gampong) yang bernama Reubee (kini Kecamatan Delima di Kabupaten Pidie). Di kampung ini terkenal dayah yang dipimpin oleh ulama bergelar Teungku Chik di Reubee. Daeng Mansyur menikah dengan seorang puteri anak Teungku Chik di Reubee tersebut dan dikaruniai dua orang anak, seorang anak perempuan yaitu Putroe Suni dan anak laki-laki bernama Zainal Abidin. Dalam catatan sejarah, masyarakat turunan Bugis Makassar yang ada di Aceh tidak terlepas dari sejarah Sultan Iskandar Muda. Awal dari sultan Aceh berdarah Bugis Makassar dimulai dengan pernikahan Sultan Iskandar Muda dengan Putroe Suni anak Daeng Mansyur (menantu Teungu Chik di Reubee). Putroe Suni ketika dewasa dipersuntung oleh Sultan Iskandar Muda sedangkan Zainal Abidin hijrah ke Aceh Besar selanjutnya terkenal dengan nama Teungku di Lhong dan ia mempunyai putra bernama Abdurrahim Maharajalela.

Cangara (2014:108) menjelaskan bahwa penulis Belanda juga menyebutkan tentang asal usul masyarakat Bugis yang ada di Aceh dengan menyebutkan adanya tiga 
orang ulama di Pidie berasal dari Sulawesi Selatan yaitu Teungku Seundri (sebenarnya adalah Sidenreng dalam logat Aceh disebut Seundri), Teungku Sigeuli yang namanya akhirnya diabadikan menjadi nama Kota Sigli, dan Daeng Mansur dari Wajo. Sultan Iskandar Muda lahir pada tahu 1590 pada masa pemerintahan Sultan Saidilmukamil (1588604). Sebelum Sultan Saidilmukamil kerajaan Aceh Darussalam dipimpin oleh Sultan Ali Riayat Syah atau Raja Buyung ( $\pm 1586-1588)$. Iskandar Muda memerintah kerajaan Aceh Darussalam dengan sangat bijak sehingga kerajaan Aceh mencapai masa gemilang. Perkawinannya dengan Putroë Suni dikaruniai seoran anak perempuan bernama Safiatuddin Syah. Safiatuddin menikah dengan Iskandar Thani berasal dari Pahang. Maka inilah awal dari adanya pemerintahan Sultanah dan Sultan keturunan Aceh-Bugis di Kerajaan Aceh Darussalam.

Nama-nama Sultan dan Sultanah Kerajaan Aceh Darussalam

\begin{tabular}{|c|c|c|c|}
\hline No & Nama Sultan & Masa Pemerintahan & Keterangan \\
\hline \multicolumn{4}{|c|}{ Sultan Aceh dari Dinasti Meukuta Alam } \\
\hline 1 & Sultan Ali Mughayat Syah & $\begin{array}{c}1496-1528 / 7 \\
\text { Agustus } 1530\end{array}$ & $\begin{array}{l}\text { Pendiri kerajaan, putera dari } \\
\text { Syamsu Syah }\end{array}$ \\
\hline 2 & $\begin{array}{l}\text { Sultan 'Adilullah bin Munawwar } \\
\text { Syah }\end{array}$ & $1528 / 1530-1540$ & $\begin{array}{l}\text { Putra dari Sultan Munawwar } \\
\text { Syah. Wafat tanggal } 30 \\
\text { Jumadal Ula } 947 \text { Hijriah } \\
(1540 \mathrm{M})\end{array}$ \\
\hline 3 & $\begin{array}{l}\text { Sultan 'Ali Ri'ayah Syah bin } \\
\text { Munawwar Syah }\end{array}$ & 1540 & $\begin{array}{l}\text { Putra dari Sultan Munnawar } \\
\text { Syah. Wafat tanggal14 } \\
\text { Sya'ban } 947 \mathrm{H}(1540 \mathrm{M})\end{array}$ \\
\hline 4 & Sultan Salahuddin & $1528 / 1530-1537 / 1539$ & $\begin{array}{l}\text { Putra dari No. 1. Wafat } \\
\text { tanggal } 25 \text { November } 1548 .\end{array}$ \\
\hline 5 & Sultan Alauddin al-Qahhar & $\begin{array}{l}1537-1568 / 28 \\
\text { September } 1571\end{array}$ & $\begin{array}{l}\text { Putra dari No. } 1 \text { dan adik } \\
\text { dari No. } 2\end{array}$ \\
\hline 6 & Sultan Husain Ali Riayat Syah & $\begin{array}{c}1568 / 1571-1575 \text { / } 8 \text { Juni } \\
1579\end{array}$ & Putra dari No. 3. \\
\hline 7 & Sultan Muda & $1575 / 1579$ & $\begin{array}{l}\text { Putra dari No. } 4 . \quad \text { Baru } \\
\text { berumur beberapa bulan pada } \\
\text { saat dijadikan sultan. }\end{array}$ \\
\hline 8 & Sultan Sri Alam & $\begin{array}{c}1575 \text { - } 1576 / \text { berkuasa } \\
\text { hanya pada } 1579\end{array}$ & $\begin{array}{l}\text { Putra dari No. } 3 . \text { Juga } \\
\text { merupakan raja Priaman }\end{array}$ \\
\hline 9 & Sultan Zainal Abidin & $\begin{array}{l}1576-1577 \text { / berkuasa } \\
\text { hanya pada } 1579\end{array}$ & Cucu dari No. 3. \\
\hline \multicolumn{4}{|c|}{ Sultan Aceh yang berasal dari luar Aceh (Asing) } \\
\hline 10 & $\begin{array}{l}\text { Sultan Alauddin } \\
\text { Syah bin Sultan Mansur } \\
\text { I (Sultan Perak } 1549 \text { - 1577) } \\
\end{array}$ & $\begin{array}{l}1577 / 1579-1589 / \\
\text { dibunuh sekitar } 1586\end{array}$ & $\begin{array}{l}\text { Kakak dari Sultan Ahmad } \\
\text { Tajuddin Syah, Sultan Perak. }\end{array}$ \\
\hline 11 & Sultan Buyong & $\begin{array}{c}1589 \text { / } 1586-1596 / 28 \\
\text { Juni1589 }\end{array}$ & Anak seorang raja Indrapura. \\
\hline \multicolumn{4}{|c|}{ Sultan Aceh dari Dinasti Darul-Kamal } \\
\hline 12 & $\begin{array}{l}\text { Sultan Alauddin Riayat Syah } \\
\text { Sayyid al-Mukammil }\end{array}$ & $1596 / 1589-1604$ & $\begin{array}{lrr}\text { Cucu } & \text { dari } & \text { saudara } \\
\text { ayahnya No. 1. } & \text { putra dari } \\
\text { Firman } & \text { Syah, } & \text { keturunan } \\
\end{array}$ \\
\hline
\end{tabular}




\begin{tabular}{|c|c|c|c|}
\hline & & & $\begin{array}{l}\text { Inayat Syah, raja Darul- } \\
\text { Kamal. }\end{array}$ \\
\hline 13 & Sultan Ali Riayat Syah & $1604-1607$ & Putra dari No. 10. \\
\hline \multicolumn{4}{|c|}{ Sultan Aceh Peleburan dari Dinasti Makota Alam dan Dinasti Darul-Kamal } \\
\hline 14 & $\begin{array}{ll}\text { Sultan Iskandar Muda } & \text { Johan } \\
\text { Pahlawan Meukuta Alam } & \end{array}$ & 1607 - 27 Desember 1636 & $\begin{array}{ll}\text { Cucu (melalui ibu) } & \text { dari No. } \\
10 \text { dan cicit } & \text { dari No. } \\
3 \text { melalui ayah. } & \end{array}$ \\
\hline \multicolumn{4}{|c|}{ Sultan Aceh yang berasal dari luar Aceh ( Asing ) } \\
\hline 15 & $\begin{array}{l}\text { Sultan Iskandar Tsani Alauddin } \\
\text { Mughayat Syah }\end{array}$ & 1636 - 15 Februari 1641 & $\begin{array}{l}\text { Putra Sultan Pahang, Ahmad } \\
\text { Syah II. Menantu dari No. } 12 \\
\text { dan suami dari No. } 14 .\end{array}$ \\
\hline \multicolumn{4}{|c|}{ Sultanah Aceh } \\
\hline 16 & $\begin{array}{l}\text { Sultanah Sri Ratu Tajul Alam } \\
\text { Safiatuddin Johan Berdaulat }\end{array}$ & $1641-1675$ & $\begin{array}{ll}\text { Putri } & \text { dari No. } \\
12 \text { dan istri dari No. } 13\end{array}$ \\
\hline 17 & $\begin{array}{l}\text { Sultanah Sri Ratu Naqiatuddin } \\
\text { Nurul Alam }\end{array}$ & $1675-1678$ & \\
\hline 18 & $\begin{array}{l}\text { Sultanah Sri Ratu Zaqiatuddin } \\
\text { Inayat Syah }\end{array}$ & $1678-1688$ & \\
\hline 19 & $\begin{array}{l}\text { Sultanah Sri Ratu Zainatuddin } \\
\text { Kamalat Syah }\end{array}$ & $1688-1699$ & $\begin{array}{l}\text { Saudari angkat dari No. } 16 \text {, } \\
\text { istri dari No. } 18 \text {, serta ibu } \\
\text { dari No. } 19 \text { dan No. } 20\end{array}$ \\
\hline \multicolumn{4}{|c|}{ Sultan-sultan Aceh Diansti Syarif (Maulana) } \\
\hline 20 & $\begin{array}{l}\text { Sultan Badrul Alam Syarif Hasyim } \\
\text { Jamaluddin }\end{array}$ & $1699-1702$ & $\begin{array}{l}\text { Suami dari No. } 17 \text {, serta ayah } \\
\text { dari No. } 19 \text { dan No. } 20\end{array}$ \\
\hline 21 & Sultan Perkasa Alam Syarif Lamtui & $1702-1703$ & \\
\hline 22 & Sultan Jamalul Alam Badrul Munir & $1703-1726$ & \\
\hline 23 & Sultan Jauharul Alam Aminuddin & 1726 & \\
\hline 24 & Sultan Syamsul Alam & $1726-1727$ & \\
\hline \multicolumn{4}{|c|}{ Keturunan Terakhir Sultan Aceh Berasal dari Keturunan Bugis } \\
\hline 25 & Sultan Alauddin Ahmad Syah & $1727-1735$ & \\
\hline 26 & Sultan Alauddin Johan Syah & $1735-1760$ & Putra dari No. 23 \\
\hline 27 & Sultan Mahmud Syah & $1760-1764$ & $\begin{array}{l}\text { Putra dari No. 24, Jabatan } \\
\text { Pertama, ditumbangkan oleh }\end{array}$ \\
\hline \multirow[t]{2}{*}{28} & Sultan Badruddin Johan Syah & $1764-1765$ & $\begin{array}{ll}\begin{array}{l}\text { Dipulihkan } \\
\text { dikembalikan kepada }\end{array} & \text { dan } \\
\end{array}$ \\
\hline & Sultan Mahmud Syah (No. 25) & $1765-1773$ & $\begin{array}{l}\text { Jabatan Kedua, Dipulihkan } \\
\text { dan dikembalikan lagi } \\
\text { kepada }\end{array}$ \\
\hline \multirow[t]{2}{*}{29} & Sultan Sulaiman Syah & 1773 & \\
\hline & Sultan Mahmud Syah (No. 25) & $1773-1781$ & Jabatan Ketiga \\
\hline 30 & Sultan Alauddin Muhammad Syah & $1781-1795$ & Putra dari No. 25 \\
\hline 31 & Sultan Alauddin Jauhar al-Alam & $1795-1823$ & $\begin{array}{l}\text { Putra dari No. } 28 . \text { Wali } \\
\text { dari No. } 27 \text { sampai } \\
\text { tahun 1802. Jabatan Pertama, } \\
\text { Digugat oleh }\end{array}$ \\
\hline 32 & Sultan Syarif Saif al-Alam & $1815-1820$ & \\
\hline
\end{tabular}




\begin{tabular}{|c|l|c|l|}
\hline & $\begin{array}{l}\text { Sultan Alauddin Jauhar al-Alam } \\
\text { No. 29) }\end{array}$ & $1795-1823$ & $\begin{array}{l}\text { Dikembalikan posisinya } \\
\text { dengan } \\
\text { bantuan Raffles, Inggris. } \\
\text { Jabatan Kedua }\end{array}$ \\
\hline 33 & Sultan Muhammad Syah & $1823-1838$ & Putra dari No. 29. \\
\hline 34 & Sultan Sulaiman Syah & $1838-1857$ & $\begin{array}{l}\text { Putra dari No. 31. Wali dari } \\
\text { No. 33 sampai 1850, digugat } \\
\text { oleh No. 33 pada 1870 }\end{array}$ \\
\hline 35 & Sultan Mansur Syah & $1857-1870$ & Putra dari No. 29. \\
\hline 36 & Sultan Mahmud Syah & $1870-1874$ & Putra dari No. 32. \\
\hline 37 & Sultan Muhammad Daud Syah & $1874-1903$ & $\begin{array}{l}\text { Cucu dari No. 33. Wali dari } \\
\text { Tuanku Hasyim } \\
\text { sampai 1884. Menyerah } \\
\text { kepada Belanda dan turun } \\
\text { takhta pada 1903. }\end{array}$ \\
\hline
\end{tabular}

Sumber:id.m.wikipedia.org.

\section{Masuknya Islam ke Sulawesi Selatan}

Mayoritas penduduk Sulawesi Selatan adalah muslim. Mereka telah memeluk agama Islam mulai dari abad ke-16. Jalur perdagangan ditempuh oleh ulama-ulama Islam untuk menyebarkan agama Islam di tanah Sulawesi. Bukan hanya di Sulawesi, di seluruh Indonesia penebaran Islam awalnya dilakukan melalui jalur perdagangan.

Samudra-Pasai, Pedie, Aceh, Palembang, Jambi, Malaka, Demak, Gresik, Tuban, Cirebon, Banten, Ternate, Tidore, Gowa-Makassar, Banjarmasin dan sebagainya, jika didasarkan kepada sumber-sumber sejarah, maka pada zaman pertumbuhan dan perkembangan Islam di Indonesia tempat-tempat tersebut di atas sudah boleh disebut kota. Diantaranya ada yang berfungsi sebagai kota pusat kerajaan, ada yang berfungsi sebagai kota-kadipaten dan ada pula sebagai kota-pelabuhan. Jika kota-kota pusat kerajaan yang bercorak Islam itu kita perhatikan letak geografisnya maka pada umumnya kota-kota tersebut terletak di pesisir-pesisir dan di muara sungai-sungai besar. Demikianlah kota-kota Samudra-Pasai, Pedie, Aceh, Demak, Banten, Ternate, Gowa-Makassar, Banjarmasin, berfungsi pula sebagai kota pusat kerajaan yang bercorak maritim, belainan dengan Pajang dan Kerta yang kedua-duanya jelas merupakan kota pusat kerajaan yang bercorak agraris (Tjandrasasita, 1975:149).

Dalam bukunya yang berjudul sejarah peradaban Islam di Indonesia, Musyrifah Sunanto (2010:27) menyebutkan bahwa Sulawesi Selatan sejak abad ke-15 M sudah didatangi pedagang Muslim, mungkin dari Malaka, Jawa, dan Sumatra. Di Gowa-Tallo raja-rajanya masuk Islam secara resmi 11 September 1605 dengan Sultan Alauddin (15911636) sebagai sultan yang pertama. Sesudah itu menyusul Soppeng, Wajo pada tanggal 10 Mei 1610 dan Bone Islam pada tanggal 23 November 1611.

Di kerajaan Bone, kerajaan Bugis paling besar yang masuk Islam tahun 1610, rajanya ke-13 La Maddaremmeng (1631-1644 M), menggabungkan hukum Islam ke dalam lembaga tradisional Bone. Ia juga mencanangkan "gerakan pembaharuan keagamaan" dengan memerintahkan kaulanya untuk mematuhi ajaran Islam secara total. Di Kerajaan Gowa-Tallo, kalau sebelum Islam hanya terdapat empat unsur yang mengawasi negara, yaitu ade, yang mengawasi rakyat, rappang, yang memperkuat negara, wari, yang memperkuat ikatan keluarga, dan bicara, yang mengawasi perbuatan sewenang-wenang, setelah Islam, unsur itu ditambah satu lagi yaitu sara', kewajiban agama. Untuk itu dibentuk lembaga yang dinamakan dengan parewa sara', pejabat agama, sebagai pendamping parewa ade, pejabat adat. Hal itu dimaksudkan untuk menciptakan aturan- 
aturan sosial yang tidak boleh bertentangan dengan ajaran agama yang diajukan oleh parewa sara' (Yatim, 2010:228).

Menilik jejak sejarah Islam di Sulawesi Selatan, akan selalu diidentikkan dengan kedatangan tiga mubalig dari Minangkabau yang disinggung di atas yakni Datuk ri Bandang, Datuk ri Tiro, dan Datuk ri Patimang. Kedatangan mereka pada abad ke-17 dianggap sebagai peletak dasar ajaran Islam di daerah ini. Tiga mubalig ini berhasil mengislamkan elite-elite kerajaan Gowa-Tallo dan menjadikan Islam sebagai agama resmi kerajaan pada tahun 1607. Menurut pakar sejarah Islam Sulsel Prof Ahmad M. Sewang, keberhasilan penyebaran Islam terjadi setelah memasuki awal Abad XVII dengan kehadiran tiga orang mubalig yang bergelar datuk dari Minangkabau. Lontara Wajo menyebutkan bahwa ketiga datuk itu datang pada permulaan Abad XVII dari Koto Tangah. Mereka dikenal dengan nama Datuk Tellue (Bugis) atau Datuk Tallua (Makassar), yaitu: Abdul Makmur, Khatib Tunggal, yang lebih populer dengan nama Datuk ri Bandang; Sulaiman, Khatib Sulung, yang lebih populer dengan nama Datuk Patimang; serta Abdul Jawad, Khatib Bungsu, yang lebih dikenal dengan nama Datuk ri Tiro. Ketiga ulama tersebut diutus secara khusus oleh Sultan Aceh dan Sultan Johor untuk mengembangkan dan menyiarkan agama Islam di Sulawesi Selatan (Amir, 2014).

Campur tangan Sultan Aceh atau raja Aceh pada masa itu, Sultan Iskandar Muda, untuk mengutus ketiga datuk yang berasal dari Sumatra Barat sebagai ulama yang berperan penting dalam Islamisasi Sulawesi Selatan tidak bisa dipungkiri lagi menjadikan alasan lahirnya hubungan antara Aceh dengan Sulawesi Selatan. Pada saat itu kerajaan Aceh dalam keadaan yang sangat jaya sehingga beliau banyak mengutus ulama-ulamanya untuk menyebarkan agama Islam ke daerah-daeran yang ada di luar kerajaan Aceh.

Sultan Iskandar Muda mempunyai beberapa nama, selain Darma Wangsa dan Perkasa Alam. Nama mudanya adalah Tun Pangkat. Setelah wilayah Aceh bertambah luas, maka dia bergelasr Mahkota Alam, atau menurut lidah Aceh: Meukuta Alam. Nama ini menjadi sebutan pula ketika dia mangkat. Jadi, dia dikenal sampai ke luar negeri dengan nama Marhum Mahkota Alam. Selain itu, ada lagi nama gelaran Sri Perkasa Alam Johan Berdaulat. Kadang-kadang orang menyebut nama lengkapnya, Perkasa Alam Maharaja Darma Wangsa Tun Pangkat (Said, 1979:230)

Pertumbuhan kerajaan Aceh disebabkan kemajuan perdagangan pada permulaan abad ke-15 Masehi. Saudagar-saudagar Muslim yang selama ini berdagang dengan Malaka, sesudah Malaka direbut Portugis, memindahkan kegiatan ke Aceh. Jalan dagang yang selama ini dari Malaka melalui selat Karimun ke laut Jawa, pindah melalui selat Sunda menyusuri pantai barat Sumatra. Oleh karena itu, kota Aceh menjadi besar. Di kota Aceh saudagar-saudagar dari berbagai bangsa berdagang, membeli dan menjual barang-barang dari berbagai negeri. Sultan Ali Mughayyat Syah adalah Sultan pertama Aceh yang membesarkan kerajaan Aceh, mengadakan hubungan internasional dengan kerajaan Turki yang pada tahun 1453 sultannya, Muhammad al-Fatih, berhasil merebut Konstantinopel yang kemudian dijadikan ibukota. Sultan Turki memberikan bantuan berupa meriam dan bendera sebagai lambang perlindungan Turki terhadap Aceh dalam kesatuan kekhalifahan Islam. Di Asia Tenggara hanya Aceh yang diakui oleh Dunia Islam, dengan demikian kedudukan Aceh bertaraf internasional. Oleh karena itu, Aceh berani menantang dan menyerang Portugis. Puncak kebesaran Aceh terjadi pada masa Sultan Iskandar Muda (1607-1636), yang menguasai seluruh pelabuhan di pesisir timur Sumatra sampai Asahan dan pantai Sumatra Barat (Sunanto, 2010:24).

Dari informasi tentang daerah-daerah yang dilalui ketiga datuk tersebut, dapat dilihat bahwa mereka memiliki pengalaman dan wawasan yang luas selama menjalankan misi keagamaan. Tidaklah mengherankan jika mereka mampu menyusun strategi dakwah sesuai dengan keadaan yang mereka hadapi. Sebagaian yang telah dikemukakan setelah 
sampai di Makassar mereka tidak langsung menyebarkan ajaran Islam kemasyarakat, melainkan mereka lebih dahulu mengumpulkan data dengan meminta informasi kepada masyarakat Melayu yang sudah lama bermukim (Rahman, 2012:54).

Dalam penelitiannya, Rahman (2012:54) menyatakan sepakat dengan pendapat Ahmad Sewang yang mengatakan demikian setelah mereka berhasil mengislamkan datuk Luwu mereka menyusun strategi baru dengan memprioritaskan daerah-daerah tertentu untuk mensyiarkan Islam selanjutnya, yaitu dengan membagi tenaga dan daerah sasaran dakwah disesuaikan dengan keahlian mereka dan kondisi daerah tugas masing-masing sebagaimana yang dikemukakan oleh Abu Hamid;

a. Datuk Ri Bandang yang dikenal sebagai ahli fikih bertugas menghadapi masyarakat Gowa dan Tallo yang masih berpegang kuat kepada tradisi lama seperti perjudian, minum ballo (tuak) dan sabung ayam. Dalam menghadapi masyarakat demikian metode dakwah yang dipakai Datuk Ri Bandang lebih menekankan pada masalah pelaksanaan hukum syariat.

b. Datuk Patimang bertugas di kerajaan Luwu yang masyarakatnya masih berpegang kuat kepada kepercayaan lama seperti Dewata seuwae. Datuk Patimang meperkenalkan ajaran Tauhid yang sederhana dengan mengemukakan sifat-sifat Tuhan seperti sifat wajib, sifat mudtahil dan sifat Ja'iz bagi Tuhan. Penekanan pada ajaran tauhid ini dimaksudkan untuk menggantikan kepercayaan Dewata seuwae menjadi keimanan kepada Tauhid yaitu Allah Yang Maha Esa.

c. Datuk Ri Tiro bertugas di Bulukumba, dengan lebih menekankan pada ajaran tasawuf sesuai kondisi masyarakat yang dihadapinya yaitu masyarakat yang masih berpegang teguh kepada masalah-masalah kebatinan, sihir dengan segala mantranya. Masyarakat Tiro memeluk kegemaran dalam menggunakan kekuatan sakti(doti) untuk membinasakan musuh. Masyarakat demikian menurut Datuk Ri Tiro akan lebih berhasil jika dilakukan dengan pendekatan Tasawuf.

\section{Etnis Aceh di Sulawesi Selatan}

Ikatan Masyarakat Aceh atau yang disingkat dengan IMA, adalah sebuah ikatan yang bertujuan untuk mengayomi dan merangkul seluruh rakyat Aceh yang ada di Makassar. IMA ini dibentuk pada tahun 1967 oleh pemulanya di generasi pertama. Kolenel Nyak Hukum, Admi Umar, Yasin, Tgk. Ali Basyah, Amin T, Abu Sofyan, Syech Ahmad, danUstad Nawawi adalah orang-orang yang pertama membentuk Ikatan Masyarakat Aceh.

Di samping Ikatan Masyarakat Aceh, ada juga Lembaga Adat Kebudayaan Aceh (LEDKA). Pengurus IMA dan LEKDA di Makassar sama. Dahulu kala mereka dilantik oleh Prof. Ali Hasyimi, Gubernur Aceh saat itu. LEDKA berpusat di Aceh, namun lembaga ini tersebar ke seluruh provinsi yang ada di Indonesia.

Kegiatan yang dilakukan oleh IMA adalah kegiatan sosial, masalah kerohanian, arisan keluarga, merayakan hari-hari besar Islam. Kebanyakan kegiatan IMA lebih intern ke dalam. Kegiatan yang bersifat di luar IMA seperti undangan-undangan dari pemerintah setempat, pertemuan raja-raja, dan lain sebagainya.

IMA adalah perwakilan dari Sulawesi Selatan. Saat ini IMA telah beranggotakan sebanyak 70 kartu keluarga. Mereka tersebar di seluruh Sulawesi Selatan. Acara arisan itulah untuk membuat para anggotanya berkumpul dan bersilaturrahmi antara sesama anggota. 


\section{Gambar Arisan IMA}
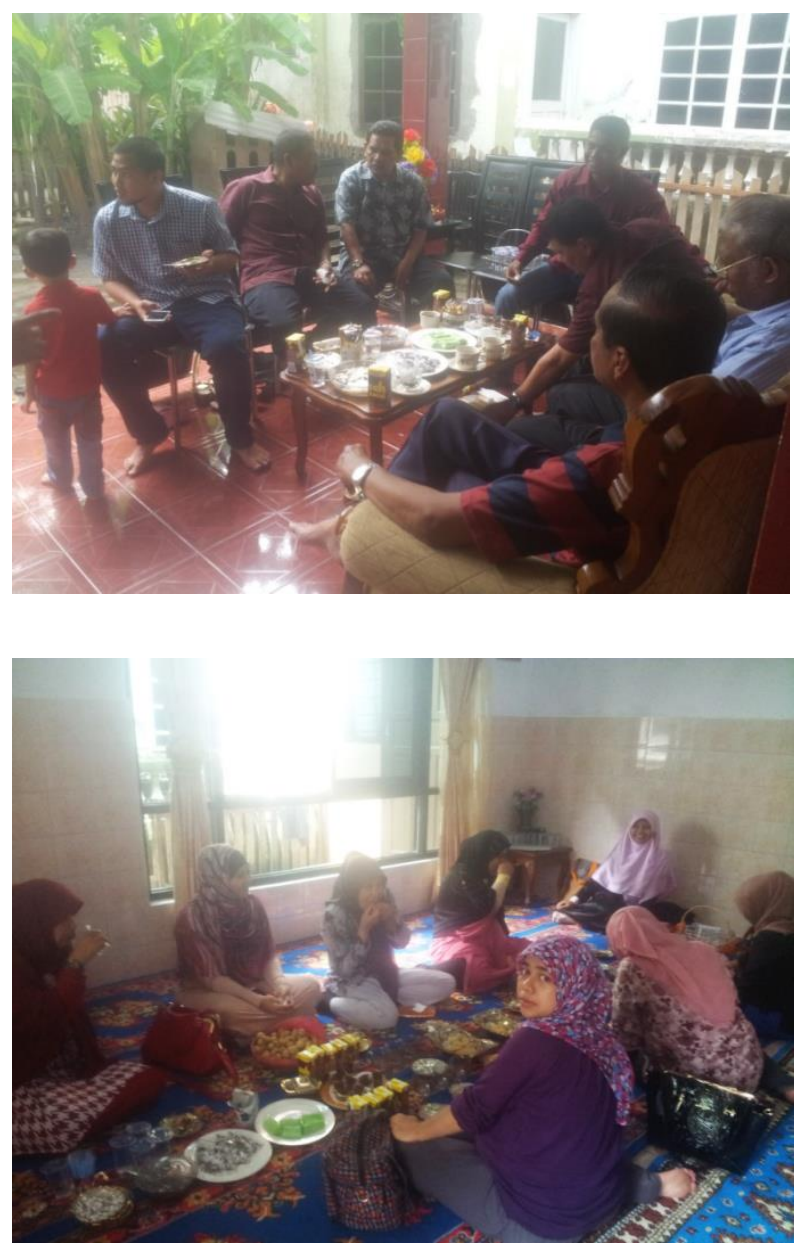

Hubungan masyarakat Aceh dengan Masyarakat Sulawesi Selatan terus ditingkatkan dan terus dilestarikan. Sejarah indah masa lalu terulang kembali dengan semakin bertambahnya perkawinan suku Aceh dengan Bugis Makassar yang melambangkan persatuan dari kedua suku tersebut. Perkawinan Etnis Aceh dengan Etnis Bugis Makassar merupakan perkawinan yang jarang terjadi. Perkawinan kedua etnis ini diawali dengan kisah merantau ke Makassar bagi para pendatang dari Aceh hingga kisah hijrah pemuda Makassar ke Aceh dan kembali lagi ke Makassar. Sikap toleransi dan saling menghargai budaya masing-masing menjadi kunci utama terciptanya kerukunan antar mereka. Seperti yang dijelaskan oleh Reni Juliani (2015 :241) dalam penelitiannya bahwa:

"Perkawinan Etnis Aceh dengan etnis Bugis-Makassar di Kota Makassar berjalan dengan baik. Komunikasi yang mereka bina dilakukan dengan menyadari perbedaan latar belakang budaya masing-masing mereka. Negoisasi mulai dari adat perkawinan sebelum menikah, bahasa yang akan mereka gunakan di dalam rumah tangga, cara mendidik anak dan mengenalkan budaya orang tua kepada anak-anak mereka. Dalam hal perbedaan perkawinan, pasangan etnis Aceh dengan etnis Bugis-Makassar sepakat menggunakan kedua budaya dalam upacara perkawinan mereka. Mereka memakai bahasa Indonesia sebagai alat komunikasi dalam keluarga termasuk dalam mendidik anak, mewariskan nilai-nilai dan 
norma-norma kehidupan di dalam rumah tangga sesuai dengan ajaran agama Islam. Mereka tidak terlalu menitik beratkan kedua budaya mereka dalam pengenalan budaya kepada anak-anak mereka. Adanya toleransi yang tinggi, kepercayaan dan kejujuran, keterbukaan satu sama lain, dan memilih mengalah untuk menang. Dalam hal mengalah dan menang adanya kecenderungan pihak istri dari pasangan suami-istri etnis Aceh dengan etnis Bugis-Makassar lebih mengalah dari pada suami mereka. Sedangkan faktor penghambat dalam proses asimilasi pasangan suami-istri etnis Aceh dengan Bugis-Makassar adalah; sifat etnosentrisme yang masih dimiliki oleh beberapa orang informan, misalnya makanan yang disajikan di rumah, makanan Aceh yang paling sering menjadi menu sehari-hari mereka, Selain dari segi makanan, cara nilai yang ditanam berlandaskan agama dan juga berlandaskan budaya Aceh. Namun sifat etnosentrisme tersebut tidak merusak perkawinan mereka karena didorong oleh rasa cinta kasih sebagai salah satu bentuk perwujudan integrasi nasional untuk saling menghargai perbedaan yang ada di antara mereka."

\section{PENUTUP}

Apabila melihat sejarah masa lalu, maka benang merah hubungan Aceh dengan Sulawesi selatan dimulai dengan hubungan perdagangan rempah-rempah, lalu hubungan perkawinan antara Sultan Iskandar Muda dengan Putroe Suni (gadis keturunan Bugis) sehingga berdampak pada sejarah masuknya Islam di Sulawesi Selatan. Seperti yang telah dijelaskan sebelumnya bahwa kehadiran 3 Datok asal Minang Kabau tersebut adalah perintah dari Sultan Iskandar Muda. Datok tersebut diutus untuk menyebarkan agama Islam di Sulawesi Selatan.

Pada masa sekarang benang merah tersebut tidak pernah terputus. Hubungan baik masih terus dijaga, sama halnya menjaga sisa-sisa peninggalan sejarah seperti makam Rajaraja Aceh keturunan Bugis yang masih terawat tepat di depan bangunan Museum Aceh. Selain itu masyarakat Aceh yang hijrah ke Sulawesi Selatan membangun sebuat Ikatan Masyarakat Aceh di Sana. IMA (Ikatan Masyarakat Aceh) merupakan wadah masyarakat untuk memperkuat hubungan kekeluargaan masyarakat Aceh yang ada di Sulawesi Selatan. Perkawinan antar kedua suku (Suku Aceh dengan Bugis Makassar) yang telah terjadi di masa lampau, juga terjadi saat ini. Perkawinan kedua suku tersebut semakin bertambah. Dengan demikian ikatan benang merah antara Aceh dan Sulawesi Selatan semakin Kuat.

\section{REFERENSI}

\section{Buku}

Abdullah, Irwan dkk. 2009. Dinamika Masyarakat dan Kebudayaan Kontemporer. Yokyakarta: Pustaka Pelajar,

Ditiro, Tengku Hasan M. 2013. Aceh di Mata Dunia. Banda Aceh: Bandar Publishing,

Hamid, Abu. 2003. Siri'dan Pesse Harga Diri Orang Bugis, Makassar, Mandar, Toraja. Makassar: Pustaka Refleksi, 
Harun, Mohd. 2009. Memahami Orang Aceh. Bandung: Citapustaka Media Perintis,

Jakobi, A.K. 2004. Aceh dalam Perang Mempertahankan Proklamasi Kemerdekaan 1945-1949 dan Peranan Teuku Hamid Azwar Sebagai Pejuang. Jakarta: Grametika Pustaka Utama,

Lubis, Lusiana Andriani. 2012. Pemahaman Praktis Komunikasi Antarbudaya. Medan: USU Press,

Pelras, Christian. 2006. Manusia Bugis. Jakarta: Nalar bekerja sama dengan Forum JakartaParis,EFEO,

Said, Mohammad. 1979. Aceh Sepanjang Abad. Medan: Harian Waspada,

Sunanto, Musyrifah. 2010. Sejarah Peradaban Islam di Indonesia. Jakarta: Raja Grafindo Persada,

Tjandrasasmita, Uka. 1975. Jaman Pertumbuhan dan Perkembangan Kerajaan-Kerajaan Islam di Indonesia. Departemen Pendidikan dan Kebudayaan,

Umar, Muhammad. 2006. Peradaban Aceh (Tamaddun) I: Mengulas Kisah Sejarah Aceh dan Adat. Banda Aceh: Yayasan Busafat,

Yatim, Badri. 2010. Sejarah Peradaban Islam Dirasah Islamiah II. Jakarta: Rajawali Pers,

\section{Tesis dan Artikel}

Cangara, Hafied, dkk. 2014. Perantau Bugis Makassar dan Penduduk Asli Daerah Tujuan Menyikapi Benih Konflik Antar Etnis dalam Rangka Harmonisasi Kehidupan Berbangsa di Indonesia Bagian Timur. Laporan Akhir tidak diterbitkan. Makassar: Universitas Hasanuddin,

Juliani, Reni. 2015. Komunikasi Antarbudaya Etnis Aceh dengan Etnis BugisMakassar melalui Asimilasi Perkawinan di Kota Makassar. Tesis tidak diterbitkan. Ujung Pandang: Program Studi Ilmu Komunikasi. Program Pascasarjana, Universitas Hasanuddin Ujung Pandang,

Rahman, Eka Yuliana. 2012. Islamisasi di Konfederasi Turatea Pada Abad XVII. Tesis tidak diterbitkan. Makassar: Program Pasca Sarjana Universtas Negeri Makassar,

\section{Internet}

Amir, Herni. Jejak Tiga Datuk di Sulawesi Selatan. http://daerah.sindonews.com/read/881803/29/jelajah-tiga-datuk-di-sulawesiselatan-1404994262/. Diakses tanggal 29 Maret 2017.

Bachtiar, Andi. 2014. Adat Bugis. http://boneputra.com Diakses tanggal 29 Maret 2017. http://ww.atjehcyber.net/2013/05/gubernur-sulsel-aceh-dan-bugis-punya-.html?m=1 . 
http://id.m.wikipedia.org/wiki/daftar-penguasa-aceh.

http://www.geni.com/people/SHEIKH-DAENG-MANSYUR/6000000005784746212.

SB, Marzuki. Jejak Suku Bugis di Tanah Kluet. http://aceh.tribunnews.com/2012/10/28/jejak-suku-bugis-di-tanah-kluet. Diakses tanggal 29 Maret 2017.

www.sejarahnusantara.com/kerajaan-islam/sejarah-masa-keemasan-kesultananaceh-darussalam-1496-1903-10036.htm 